\title{
Analysis of the Philosophical Category Reflection "Relationship/Communication" in the Kyrgyz Family
}

\section{Venera Dzhanibekova1, Kanyshai Nurdinova1, Gulumbu Tokoeva², Gulzat Amatova², Dunuiakan Eshenalieva2, Zhypargul Abdullaeva ${ }^{3 *}$ (1)}

${ }^{1}$ Department of International Relations, Osh State University, Osh, Kyrgyzstan

${ }^{2}$ Department of Philosophy and Political Science, Osh State University, Osh, Kyrgyzstan

${ }^{3}$ Science and Research Department, Osh State University, Osh, Kyrgyzstan

Email: *jypar.science@oshsu.kg

How to cite this paper: Dzhanibekova, V., Nurdinova, K., Tokoeva, G., Amatova, G., Eshenalieva, D., \& Abdullaeva, Z. (2021). Analysis of the Philosophical Category Reflection "Relationship/Communication" in the Kyrgyz Family. Open Journal of Philosophy, 11,28-34.

https://doi.org/10.4236/ojpp.2021.111003

Received: December 14, 2020

Accepted: January 15, 2021

Published: January 18, 2021

Copyright $\odot 2021$ by author(s) and Scientific Research Publishing Inc. This work is licensed under the Creative Commons Attribution International License (CC BY 4.0).

http://creativecommons.org/licenses/by/4.0/

\begin{abstract}
The article describing family marriage relations and their peculiarities between the ancient Kyrgyz people, the main focus was directed on the philosophical relation categories. Formation of the relationship proves the development of an organic type of communication in the form of a traditional family. According to the general philosophical concept, the Kyrgyz family is not only closely connected with its members, but also has formed a way of life and social norms that belong to the people as a whole.
\end{abstract}

\section{Keywords}

Social Relations, Organic Type, Mechanical Type, Family Relations, Nomadic Culture, Wind Force, Tribe

\section{Introduction}

The whole spiritual wealth, language, culture, and morality (Stokhof, 2018) created by mankind are formed from the daily life relationships between people. A human is considered as a member of society (van Leeuwen et al., 2018), developing various natural and social skills. Each stage of social development is unique; it reflects the processes, phenomena, patterns of the world, and the formed, developed relations between nature and humans. As a concept, development is associated with meanings, interpretations and is defined as an evolutionary process in which the human capacity increases in terms of initiating new structures, solving problems, adapting to changes (Mensah, 2019). Social phe- 
nomena are complex and multidimensional, characterized by relationships and interactions between individuals living in groups and within social contexts such as families, neighborhoods, and schools (McDade \& Harris, 2018).

Without social relations, there can be no society and no person "in general". As the great idealist, Plato defined, "general ideas" as eidos, which means live in the real material world in the form of their copies and the form of perfect personal incarnations. The same meaning applies to social relations in two ways: first is the attributive form of their (people's) connection, which is the special essence of existence or historical reasons that explain the people to whom they are united; second is the social relations as one of the different relationships between people living in the same place and at the same time in society (Plato, 1999). The transition to parenthood and to old age is related to changes in quantity and quality of social relations (David-Barrett et al., 2016).

Research problem is related to conditions facilitating activities of humankind in everyday life between people. The relationship between man and woman, between parent and child, between the older generation and youth, kinship and other relationships is a complicated moment. Relationship is a philosophical analysis of the communication evolution, which requires understanding, comparing and evaluating the direction and values of social relations, which are being transformed under the influence of various modern factors.

A research objective is the reflection of philosophical categories and communication in the family as a social institute.

Today, human life activities are greatly facilitated by the achievements in science and technology, but the relationship between people, communities, and groups is complicated. This scientific analysis confirms the process of transformation of the category of communication. Intercultural communication represents interethnic, interracial, and intergroup communication types (Kim, 2007). Family is an important philosophical category shaping the children's communication values, and humanity's most fundamental social institution (Barbato et al., 2003; Koerner \& Schrodt, 2014). Family communication behavior between family members closely related to family communication patterns, (Koerner \& Anne, 2002). According to the family systems theory, family function refers to processes with interactions between members involved to meet their needs, make decisions, define goals, establish rules for themselves and for the system as a whole (Procentese et al., 2019). The main parental resource categories were mentioned such as 1) material resources, representing financial wealth and anything that can be obtained with money; 2) cognitive resources, which refer to the family's intellectual environment including the time used in teaching children; and 3) interpersonal resources that encompass parental attention, love, encouragement, and time (Chen \& Liu, 2014).

\section{The Ancient Kyrgyz People Formation}

The earliest information about the ancient Kyrgyz dates back to BC. In describ- 
ing the conquests of Maodun or Mode, the leader of the Hunnu Shan Yuya tribes in 201, the Chinese historian Sima Qian wrote about the Gegun tribes and warned that he explained the ethnonym "Kyrgyz" (Dzhanibekova, 2014).

The Kyrgyz people life and culture from the ancient times to early Middle Ages was studied mainly based on archeological, anthropological, ethnological materials, Kyrgyz epics, the Kyrgyz language history, and image of historical processes formed. Specialist in the Kyrgyz people ethnographic history S. M. Abramzon in his work named "Kyrgyzs, their ethnological, historical and cultural ties" analyzed the nature and direction of ethnic processes and came to the following conclusions: 1 ) The process of formation of the tribes that make up the Kyrgyz people took place in the Eastern Tenir-Too, Inner Tenir-Too, Pamir Alai and Altai mountainous areas; 2) The following tribes formed the Kyrgyz people basis in the XIV-XVIII centuries: a) local Turkic-speaking tribes living in these territories in the past; b) foreign groups, mainly Turkic-speaking tribes of Central Asian origin; c) Mongol and Kazakh-Nogai tribes, d) Yenisei Kyrgyz participated in the formation of the Kyrgyz people in the Tenir-Too region (Abramzon, 1984).

The process of Kyrgyzs formation as a people took place in the XIV-XVIII centuries, and before that time, Kyrgyzs reflected in the tribal structures, which is the reflection of their relationship. The issue of Kyrgyz family and marital relations are even more complicated, as the formation of family relations goes far beyond that. In the first half of the twentieth century, a great contribution to the development of concepts and categories in the social philosophy made, and two directions in the history of the human relations development were identified, where the first is communal or organic), and the second is social or mechanical (Tennis, 2002).

The first, social (organic) type of social connection is the closest, most sincere connection between people. Emotions, such as love, affection, and interdependence, are conditioned by emotional and psychological characteristics and create the organic integrity of communication. Formation of social communication is based on phenomena such as rational trade, selection, exchange, which reflects the second type of social (mechanical) unity. Organic and mechanical types of communication are not only the characteristics of human communication with each other, but also the sum of their relationships with society and nature. These types of communication differ in their structural structure. If each of the elements that make up the structure of social relations forms a priority and plays a key role in its operation, the set of parts in the structure of social relations creates a whole, and the autonomy of the elements that make it up is lost. The difference between community and public associations is organic and mechanical connection of the components that form the essence of social integrity. The first family we are talking about the family relationship reflecting an organic connection. The period of formation of the common features of the Kyrgyz people as a nation, such as psychology, emotional thinking, and instinct, goes back to the time when the laws of exogamy in the tribal and patriarchal system came into force. 
We know that in the ancient Central Asia there were many people, some of whom were assimilated by other people, and some of them completely disappeared from the historical arena.

\section{Kyrgyz Tribes Formation}

The process of the Kyrgyz tribes formation took place in the Eastern Tien-Shan, Inner Tien-Shan, Pamir Alai, and Altai mountainous areas, in close contact with the Slavic peoples in the north-east and west, the Chinese people in the south-east and the tribes of modern Iran. No efforts have been made to assimilate and adapt to the written and linguistic culture of the peoples, the systemic structure of social governance, moral and traditional customs, and the culture of economic management. The social culture of the nomads developed in stark contrast to the Slavic, Chinese, and Iranian peoples, despite their proximity. We have considered formation of their ethnographic identity in terms of their adaptation to the natural conditions of the region and their economic potential. Adaptation to the dynamic state of the landscape does not play a key role in the formation of the nomadic community. The importance of organic-community communication is great. The inner spirit creates an attitude towards the processes taking place in nature and society in the world and ensures that each individual lives in a community.

\section{Social Communications Formation}

Organic communication relations were formed and developed in the growing families of the ancient people living in a communal structure. In ancient times, before the emergence of other social institutions of society, the family was formed from the trust of people, the relationship between men and women based on feelings, thoughts, faces (love, hope, and faith). It is a mistake to think that co-farming is a key factor in the development of family relationships. People's efforts to meet their needs, such as food, clothing, and housing, have a certain effect on the development of communication. However, the inner unity between man and woman has developed since the first human beings began to take shape as human beings. There is a core like an inner spirit based on different commonalities including tribe, people, nation, group, etc. (Dzhanibekova, 2014).

From the development of family relations to the system structure of other human society social units (primary natural forms of division of labor between men and women, parents and children, the basis of the economic environment, the formation of patriarchy, the formation of gender segregation in society, exogamy is tribal relations substantiation of the formation of social groups with the systematization), the mechanical connection of social integrity, that is, the formation of rational, abstract and rational relations, reflecting the totality of the formation of formal social groups. The organic-bond nature of social unity is inherently qualitatively stable and can contribute to the development of me- 
chanical bonds.

At the same time, the change in the mechanical connection affects the essence of unity in the systemic structure, and the fact that the content of the organic connection becomes a necessary condition for adaptation to society explains the dialectical relationship. For example, the periodic formation peak of the concept "Kyrgyzness" in the social psychology of today's Kyrgyz goes back to the time of the family relations formation in the ancient times. At that time, this concept included a set of values that were unique to the Kyrgyz people (care for orphans and widows, protection of the Motherland, the honor of the people), but retained its form and changed its essence under the influence of various social factors in the historical space (Dzhanibekova, 2014). Since the beginning of 21st century, the concept "Kyrgyzness" has been viewed as a "belt of honor" that belongs to the Kyrgyz people, and the practice of holding funerals and weddings for the sake of the Kyrgyz mentality.

Therefore, just as it is impossible to create the life itself artificially, it is impossible to create connections of organic integrity through artificial means, which wants to preserve the core content and essence. The nomadic and semi-nomadic Kyrgyz family, based on a tribal-patriarchal structure in the Middle Ages, lived in close contact with nature, and the relationship between its members was based on "natural democracy". The term "natural democracy" is not used in the sense that it refers to the social culture of barbarians, as has been the case in Europe.

This concept reflects the harmonious relationship between nature and social community as the relationship between man and woman, parent and child, which is based on the laws of everything in nature, the role, and place of the object, the place of each family member shaped according to the feature. The man not only provided the family with daily necessities and protection from various dangers but also lived by the spiritual principles and norms of true nomads. Therefore, the "father" is seen as a living source of faith for his children.

The mother not only gave birth to children and prepared their food, but also brought up family members who were able to learn about the nature of the younger generation, interact and ensure their safety. Children were valued for carrying, preserving, and passing on from generation to generation the spiritual faith that passed through generation to generation. The child's responsibility is to pass the great heritage of father, the tribe to the next generation, without compromising the "name of the fathers" living in the spirit of every Kyrgyz. Therefore, the essence of the tribes' formation as a people was formation of inner living spiritual relationship, and the worship of "ancestors" has been preserved in the history.

\section{Worship as a Culture}

"Worship" is the main part of the culture of the people, being its inner sacred nucleus, the natural, chaotic and accidental desires of the man turned his inten- 
tions into a permanent spiritual connection of his existence. It recreates man, who is a part of nature, into a spiritual being, and strengthens such values as eternal remembrance, love and shame, and faith. In their activities, nomads have developed the ability to navigate the multifaceted world, using the great spiritual values formed because of the cult of worship. Worship depends not only on space but also on time and the holding of sacrificial events.

The worship of the Kyrgyz "ancestors" reflected in the formation and development of the concept "seven fathers" in family relations. Nomads occupied a vast area, to rule over the war and peace between people, and to exterminate or assimilate certain people. It is the natural and innate to Kyrgyz people to define their unity through the branches of the "seven fathers" without getting lost in the spatial chaos. The "ancestral branch" defined the identity, present, and future, and commonplace and role of each member of the family living at that time (Dzhanibekova, 2014).

\section{Conclusion}

With the evolution of society, it is clear that interests began to play a key role in the formation of today's Kyrgyz family relations, giving way to organic relations of mechanical relations. There is no doubt that the family, which is at the forefront of the formation and development of social relations, is being transformed today under the influence of socio-economic factors in society, and the relationship requires a study of the main factors, directions, and consequences of current changes. The ancient Kyrgyz people and tribes formation, social communication formation related to family philosophical categories and customs described.

\section{Conflicts of Interest}

The authors declare no conflicts of interest regarding the publication of this paper.

\section{References}

Abramzon, S. M. (1984). Kyrgyz and Their Ethnogenetic and Historical-Cultural Ties (403 p.). Frunze: Kyrgyzstan.

Barbato, C. A., Graham, E. E., \& Perse, E. M. (2003). Communicating in the Family: An Examination of the Relationship of Family Communication Climate and Interpersonal Communication Motives. Journal of Family Communication, 3, 123-148. https://doi.org/10.1207/S15327698JFC0303 01

Chen, Z. Y., \& Liu, R. X. (2014). Comparing Adolescent Only Children with Those Who Have Siblings on Academic Related Outcomes and Psychosocial Adjustment. Child Development Research, 2014, Article ID: 578289. https://doi.org/10.1155/2014/578289

David-Barrett, T., Kertesz, J., Rotkirch, A., Ghosh, A., Bhattacharya, K., \& Monsivais, D. (2016). Communication with Family and Friends across the Life Course. PLoS ONE, 11, e0165687. https://doi.org/10.1371/journal.pone.0165687

Dzhanibekova, V. B. (2014). Discussion of the Growth of Changes in the Values of Kyr- 
gyz Family Relations (Historical and Philosophical Analysis) (105 p.). Monography. Osh.

Kim, Y. Y. (2007). Ideology, Identity, and Intercultural Communication: An Analysis of Differing Academic Conceptions of Cultural Identity. Journal of Intercultural Communication Research, 36, 237-253. https://doi.org/10.1080/17475750701737181

Koerner, A. F., \& Schrodt, P. (2014). An Introduction to the Special Issue on Family Communication Patterns Theory. Journal of Family Communication, 14, 1-15. https://doi.org/10.1080/15267431.2013.857328

Koerner, F. A., \& Anne, F. M. (2002). Understanding Family Communication Patterns and Family Functioning: The Roles of Conversation Orientation and Conformity Orientation. Annals of the International Communication Association, 26, 36-65. https://doi.org/10.1080/23808985.2002.11679010

McDade, T. W., \& Harris, K. M. (2018). The Biosocial Approach to Human Development, Behavior, and Health across the Life Course. The Russell Sage Foundation Journal of the Social Sciences: RSF, 4, 2-26. https://doi.org/10.7758/RSF.2018.4.4.01

Mensah, J. (2019). Sustainable Development: Meaning, History, Principles, Pillars, and Implications for Human Action: Literature Review. Cogent Social Sciences, 5, Article ID: 1653531. https://doi.org/10.1080/23311886.2019.1653531

Plato (1999). Dialogues (338 p.). Kharkiv: Folio.

Procentese, F., Gatti, F., \& Di Napoli, I. (2019). Families and Social Media Use: The Role of Parents' Perceptions about Social Media Impact on Family Systems in the Relationship between Family Collective Efficacy and Open Communication. International Journal of Environmental Research and Public Health, 16, 5006.

https://doi.org/10.3390/ijerph16245006

Stokhof, M. J. B. (2018). Ethics and Morality, Principles and Practice. Zeitschrift für Ethik und Moralphilosophie, 1, 291-304. https://doi.org/10.1007/s42048-018-0016-x

Tennis, F. (2002). Community and Society (226 p.). Saint Petersburg: Vladimir Dahl.

van Leeuwen, E. J. C., Cohen, E., Collier-Baker, E., Rapold, C. J., Schäfer, M., Schütte, S., \& Haun, D. B. M. (2018). The Development of Human Social Learning across Seven Societies. Nature Communications, 9, Article No. 2076.

https://doi.org/10.1038/s41467-018-04468-2 